\title{
Evolutionary ecology, systematics, speciation, and phylogeography in benthology-preface
}

\author{
Michael T. Monaghan ${ }^{1,5}$, Steffen U. Pauls ${ }^{2,6}$, Jane M. Hughes ${ }^{3,7}$, AND \\ Christopher T. Robinson ${ }^{4,8}$ \\ ${ }^{1}$ Leibniz-Institute of Freshwater Ecology and Inland Fisheries (IGB), Müggelseedamm 301, 12587 Berlin, \\ Germany \\ ${ }^{2}$ Department of Entomology, University of Minnesota, St Paul, Minnesota, 55108 USA \\ ${ }^{3}$ Griffith University, Australian Rivers Institute, Griffith School of Environment, 170 Kessels Road, \\ Nathan, Queensland, Australia 4111 \\ ${ }^{4}$ Eawag, Swiss Federal Institute of Aquatic Science and Technology, 8600 Duebendorf, Switzerland and \\ ETH Zürich, Institute of Integrative Biology, Switzerland
}

The $1^{\text {st }}$ special session to feature evolutionary and genetics research at a North American Benthological Society (NABS) Annual Meeting was held during the $47^{\text {th }}$ annual meeting (1999, Duluth, Minnesota). That session was largely an attempt to gather what was, to that point, a scattered and small group of researchers who were studying dispersal, were using genetic techniques, or both. Two sessions totaling 15 talks reported research on bacteria, mussels, insects, and fish. Special sessions of similar size and scope also were held during the $50^{\text {th }}$ annual meeting (2002, Pittsburgh, Pennsylvania), the $54^{\text {th }}$ annual meeting (2006, Anchorage, Alaska), and the $57^{\text {th }}$ annual meeting (2009, Grand Rapids, Michigan). The following special series of papers originates primarily from the 2009 session, with a few additional studies.

What has become obvious to participants and attendees of these sessions over the years is the increasing diversity of evolutionary research within the NABS research community. Many of the studies presented in the 2002 meeting were based on allozyme markers, and most of the research programs were in a descriptive phase. In the meantime, short sequences of mitochondrial and nuclear deoxyribonucleic acid (DNA) have been added to the standard methods, and studies are increasingly hypothesis driven. More significant is that authors of most of the studies in this series used one or more methods from classical taxonomy, ecology, behavior, molecular systematics, phylogeography, and population genetics, a fact that underscores the value of a multidisci-

\footnotetext{
${ }^{5}$ E-mail addresses: monaghan@igb-berlin.de

6. pauls497@umn.edu

7 jane.hughes@griffith.edu.au

8 christopher.robinson@eawag.ch
}

plinary approach to ecological and evolutionary questions (see also Holzenthal et al. 2010). We found it easier to group the papers by the topic they addressed than by the methods used or the taxa examined.

The series begins with contributions that offer new insights into some old problems. The study of microorganisms has remained largely functional because of the difficulties encountered when studying microbial community structure. Microbial ecologists are faced with an enormous taxonomic diversity in environmental samples, cryptic morphologies that are difficult to relate to species-level differences, and a fundamental lack of a widely applicable concept of microbial species. Bärlocher (2010) provides a comprehensive discussion of how molecular techniques can be applied to the study of aquatic fungal communities to better understand the relationship(s) between community structure and function.

Taxonomic problems are not limited to the microbial world, and many early genetic studies of the benthos focused on taxonomic problems (Monaghan and Sartori 2009, Holzenthal et al. 2010). In the present series, a number of authors used modern molecular tools in combination with other data to solve taxonomic problems. Pauls et al. (2010) examined several closely related, codistributed species of Smicridea caddisflies (Trichoptera:Hydropsychidae) with a combination of morphological characters and range-wide genetic variation in the mitochondrial DNA barcoding region. They described 2 new species, recognized 5 other genetically distinct, but morphologically cryptic lineages, and concluded that DNA barcode data are useful for delimiting species and associating life stages in this genus. Gattolliat and Monaghan (2010) used DNA sequences, the coales- 
cent-based general mixed Yule-coalescent (GMYC) model (Pons et al. 2006), morphological taxonomy, and phylogenetics to study the highly diverse tropical mayfly (Ephemeroptera) fauna of Madagascar. They linked immature and adult life stages of undescribed species, described a new species, and established the new genus Adnoptilum (Baetidae). Ujvárosi et al. (2010) used field samples and museum collections together with morphological taxonomy and DNA sequences to study cryptic diversity within the European crane fly Pedicia occulta (Diptera:Pediciidae). Their combined data supported the presence of cryptic species and provided further evidence for the important role of the Carpathians as a glacial refuge and center of speciation.

Analysis of DNA sequence data also can provide insight into the history of a species by examining how historical changes in climate and geography contributed to present-day distributions (Avise 2000). The field of phylogeography continues to be a major research topic in freshwater research, and the following authors reported on a wide range of taxa and regions. Kubow et al. (2010) found 4 distinct genetic lineages of the caddisfly Allogamus uncatus (Trichoptera:Limnephilidae) in the European Alps. These lineages corresponded to multiple glacial refugia with more recent colonization of valleys and relatively rapid differentiation and local endemism of populations. Lehrian et al. (2010) examined a montane caddisfly, Chaetopterygopsis maclachlani (Trichoptera: Limnephilidae), across Europe and also found deeply diverged genetic lineages that appear to correspond to refugial populations. These populations have since begun to diverge into independent eastern and western European lineages. Ujvárosi et al. (2010) also found that populations of a crane fly are highly localized. Cook and Hughes (2010) studied the historical effects of changing sea levels at a similar time scale. Connectivity between Australia and New Guinea was most recently lost 6000 to 8000 y before present (ybp), but divergence among populations of the pennyfish Denariusa bandata (Perciformes:Ambassidae) appears older and more complex than a single recent event. Instead, sequential divergence occurred within Australia before separation of populations across the oceanic barrier.

Population genetic studies continue to provide information about population history that can have important implications for freshwater conservation. Stutz et al. (2010) compared 2 species with overlapping distributions in springs of the North American Great Basin. Hyalella azteca (Amphipoda:Gammaridea) had a much more pronounced genetic structure than did Callibaetis americanus (Ephemeroptera:Baeti- dae), and this difference appears to have arisen from differences in the time since colonization of these ecosystems and differences in present-day levels of gene flow. Huey et al. (2010) found restricted dispersal of the fish Ambassis macleayi in tropical northern Australia despite high habitat connectivity during annual monsoon rains and historically through lake Carpentaria ( $10,000 \mathrm{ybp})$. The result is that each catchment contains unique genetic diversity.

Local adaptation of populations is an important step in the process of speciation (Orr 2005). Seidel et al. (2010) report that a combination of reduced gene flow and adaptation to different levels of salinity might drive diversification in the Gammarus pecos (Amphipoda:Gammaridea) species complex in the Chihuahuan Desert of North America. Fawcett et al. (2010) studied the admixture of 2 populations of the shrimp Paratya australiensis (Decapoda:Atyidae) in a catchment of the Brisbane River in Queensland, Australia. Their data suggest 2 highly divergent populations, with the newly introduced individuals having higher reproductive success but low survival and, therefore, reduced overall fitness compared to the resident population.

In summary, the collection of papers covers a broad range of current topics in evolutionary ecology and repeatedly highlights the advantage of using multiple approaches (e.g., genetics, ecology, natural experiments, museum collections) to answer important but complex questions. We hope it inspires others to integrate genetic techniques into their work and that it leads to further research on the broad range of topics presented.

\section{Acknowledgements}

This special series is dedicated to the memory of our colleague Richard Seidel (1975-2010), who died suddenly very early in his career. Rick contributed to the 2009 Special Session in Grand Rapids and his paper appears in the following special series. We are grateful to Pamela Silver for her editorial expertise and continuous encouragement in the preparation of the special series.

\section{Literature Cited}

Avise, J. C. 2000. Phylogeography: the history and formation of species. Harvard University Press, Cambridge, Massachusetts.

BÄRLOCHER, F. 2010. Molecular approaches promise a deeper and broader understanding of the evolutionary ecology of aquatic hyphomycetes. Journal of the North American Benthological Society 29:1027-1041. 
CoOK, B. D., AND J. M. Hughes. 2010. Historical population connectivity and fragmentation in a tropical freshwater fish with a disjunct distribution (pennyfish, Denariusa bandata). Journal of the North American Benthological Society 29:1119-1131.

Fawcett, J. H., D. A. Hurwood, And J. M. Hughes. 2010. Consequences of a translocation between two divergent lineages of the Paratya australiensis (Decapoda:Atyidae) complex: reproductive success and relative fitness. Journal of the North American Benthological Society 29: 1170-1180.

Gattolliat, J.-L., And M. T. Monaghan. 2010. DNA-based association of adults and larvae in Baetidae (Ephemeroptera) with the description of a new genus Adnoptilum in Madagascar. Journal of the North American Benthological Society 29:1042-1057.

Holzenthal, R. W., D. R. Robertson, S. U. Pauls, and P. K. Mendez. 2010. Taxonomy and systematics: contributions to benthology and J-NABS. Journal of the North American Benthological Society 29:147-169.

HueY, J. A., A. M. BaKer, AND J. M. Hughes. 2010. High levels of genetic structure in the Australian freshwater fish, Ambassis macleayi. Journal of the North American Benthological Society 29:1148-1160.

Kubow, K. B., C. T. Robinson, L. N. S. Shama, and J. Jokela. 2010. Spatial scaling in the phylogeography of an alpine caddisfly, Allogamus uncatus, within the central European Alps. Journal of the North American Benthological Society 29:1089-1099.

Lehrian, S., M. BÁlint, P. HaAse, and S. U. Pauls. 2010. Genetic population structure of an autumn-emerging caddisfly with inherently low dispersal capacity and insights into its phylogeography. Journal of the North American Benthological Society 29:1100-1118.
Monaghan, M. T., and M. Sartori. 2009. Genetic contributions to the study of taxonomy, ecology, and evolution of mayflies (Ephemeroptera): review and future perspectives. Aquatic Insects 31(Supplement 1): 19-39.

ORR, H. A. 2005. The genetic theory of adaptation: a brief history. Nature Reviews Genetics 6:119-127.

Pauls, S. U., R. J. Blahnik, X. Zhou, C. T. Wardwell, and R. W. Holzenthal. 2010. DNA barcode data confirm new species and reveal cryptic diversity in Chilean Smicridea (Smicridea) (Trichoptera:Hydropsychidae). Journal of the North American Benthological Society 29: 1058-1074.

Pons, J., T. G. Barraclough, J. Gomez-Zurita, A. Cardoso, D. P. Duran, S. Hazell, S. Kamoun, W. D. Sumlin, and A. P. VogLer. 2006. Sequence-based species delimitation for the DNA taxonomy of undescribed insects. Systematic Biology 55:595-609.

Seidel, R. A., B. K. LANG, AND D. J. Berg. 2010. Salinity tolerance as a potential driver of ecological speciation in amphipods (Gammarus spp.) from the northern Chihuahuan Desert. Journal of the North American Benthological Society 29:1161-1169.

Stutz, H. L., D. K. Shiozawa, and R. P. Evans. 2010. Inferring dispersal of aquatic invertebrates from genetic variation: a comparative study of an amphipod and mayfly in Great Basin springs. Journal of the North American Benthological Society 29:1132-1147.

Ujvárosi, L., M. BÁlint, T. SChMitT, N. MéSZÁros, T. UjvÁrosi, AND O. Popescu. 2010. Divergence and speciation in the Carpathians area: patterns of morphological and genetic diversity of the crane fly Pedicia occulta (Diptera:Pediciidae). Journal of the North American Benthological Society 29:1075-1088. 